\title{
The Association of Board Composition, Intellectual Capital and Firm Performance in a High Ownership Concentration Context: Evidence from Italy
}

\author{
Stefania Veltri ${ }^{1} \&$ Romilda Mazzotta ${ }^{1}$ \\ ${ }^{1}$ Department of Business Administration and Law, University of Calabria, Italy \\ Correspondence: Stefania Veltri, Department of Business Economics, University of Calabria, Italy. E-mail: \\ stefania.veltri@unical.it
}

Received: June 30, 2016

Accepted: August 6, $2016 \quad$ Online Published: September 20, 2016

doi:10.5539/ijbm.v11n10p317

URL: http://dx.doi.org/10.5539/ijbm.v11n10p317

\begin{abstract}
The association of Corporate Governance (CG) with Firm Performance (FP) has always been an issue relevant to management literature. Nevertheless, the notable heterogeneity of studies and their mixed results highlight the opportuneness of continuing to investigate the association of CG with FP. The article aims to contribute to this research by building and employing a sophisticated model to take into account beyond the board composition ownership structure and firm efficiency in using its intellectual capital (as measured by VAIC ${ }^{\mathrm{TM}}$ ). The findings provide evidence that the board composition, the ownership concentration and the efficiency of intellectual capital increases firm efficiency in producing profits (as measured by ROA). Furthermore, our findings add knowledge to the relationship between CG and FP, by confirming a positive relationship in Italy, a continental European capital market under-investigated on this issue
\end{abstract}

Keywords: corporate governance, firm performance, board composition, intellectual capital, ownership concentration, ROA, Italy

\section{Introduction}

Studies in the literature on the association of Corporate Governance (CG) with Firm Performance (FP) are characterized by marked heterogeneity, which has led to mixed results.

This article adds knowledge on the issue by designing a research framework to unveil the association of CG with FP by including other variables in the right side of the model supposed to affect performance variations, namely the ownership structure (OS) and the intellectual capital (IC) performance of the firms.

CG is measured with board independence as, consistently with the majority of the literature (Fama \& Jensen, 1983; Hermalin \& Weisbach, 1991), we believe the board of directors is the main monitoring tool whose principal task is to monitor shareholders, in the light of agency theory.

Variable ownership structure has been added because, consistently Aceiro Fraile and Alcade Fradejas (2014), we believe not only that it characterizes entire contexts and is therefore responsible for the differences in CG across countries, but also it affects the board of directors and firm performance (Acero Fraile \& Alcade Fradejas, 2014; Perini et al., 2008; Barontini \& Caprio, 2006).

Intellectual capital efficiency has been included in the model as we, consistently with Keenan and Aggestam (2001), believe the efficiency of a firm in using its key tangible and intangible resources affects the CG.

In the article firm performance is measured by Return on Assets (ROA) as this ratio measures firm efficiency in producing profits, and is therefore complementary with the variable used to measure IC efficiency: the VAIC ratio.

This complex and holistic framework has been applied to non-financial Italian listed companies in the three-year period 2008-2010. The Italian context was chosen for its peculiarities under a CG profile.

To the best of our knowledge, this is the first model which investigates the relationship between CG and FP including OS and IC as explanatory variable and this is the main originality of the paper.

The findings provide evidence of the better explanatory power of this holistic model, so adding knowledge to the 
lively debate on the CG-FP issue.

\section{Literature Review}

Companies are managed through corporate governance choices. An effective corporate governance is thus expected to provide more reliability of public disclosures, to reduce the cost of capital and to improve firm effectiveness, so affecting firm performance (Jaggi et al., 2016; Mazzotta \& Veltri, 2014).

In an agency theory framework, the boards of directors is considered a key CG monitoring tool; its primary role is connected to the separation between ownership and management in organizations and to the necessity of controlling the agent (that is, manager) who acts on behalf of the principal (that is, shareholder) (Hermalin \& Weisbach, 1991; Bachiller et al., 2016). An effective board is thus expected to lead to improved financial performance of the firm (Conheady et al., 2015).

Many studies have tried to understand the influence the board characteristics have on company performance. With respect to the board composition, the most relevant aspect is the presence of insider and outsider directors or, from another perspective, the presence of executive, non-executive and independent, and non-executive but non-independent directors. Empirical studies investigating the relationship between board composition and FP found mixed results. Some studies found a negative correlation between these variables (Agrawal \& Knoeber, 1996; Bhagat \& Black, 1999), others supported the idea of a positive correlation between the variables (Dahya \& McConnell, 2007), others found a not statistically significant relation between the two variables (Hermalin \& Weisbach, 1991).

Recently, research frameworks started to include ownership structure, as in contexts where equity ownership is highly concentrated, the corporate governance problem is not a problem between shareholders (principals) and managers (agents (type I problem), instead it is focused on the relationship between small and large shareholders (type II agency problem). In this second case, the board of directors is called to broaden the scope of its supervisory function to safeguard the interests of small shareholders (Baglioni \& Colombo, 2013).

As regards empirical studies addressed to investigate the association of the board of directors with the FP (including the ownership structure variable and effected in high ownership concentration contexts), the evidence is inconclusive: the research of Baglioni and Colombo (2013) in the Italian context shows firm performance is negatively affected by the share of independent members on the board and positively affected by the share of executive members; the research of Jameson et al. (2014) finds that controlling shareholders board membership in Indian firms has a statistically significant negative association with the FP measured by Tobin's Q, in contrast to the findings of Anderson and Reeb (2004) in the US context. Some studies deepen the analysis on the outsider membership of the board by differentiating between nominee and independent directors. Nominee directors represent significant shareholders, whereas independent directors do not have any type of relationship with the organization. Such a distinction is really important in high ownership concentration contexts, as are the independent directors who are asked to safeguard the interests of small shareholders (Acero, Fraile, \& Alcade Fradejas, 2014). The research of Lefort and Urzúa (2008), based on a sample of Chilean firms, evidences that the proportion of outside directors appears to affect company value but, when separating the proportion of independent and nominee directors, the analysis finds only the proportion of independent directors positively affects company value. The research of Leung et al. (2014), based on a sample of Hong Kong firms, finds no significant association of the independence of corporate boards or board committees with firm performance in family firms, whereas board independence is positively associated with firm performance in non-family firms (Note 1). Kouki and Guizani (2015), in their research based on Tunisian firms, find that family ownership negatively moderates the outside directors-FP relationship, and Reyna et al. (2012) in their research on the high ownership concentrated context of Mexico find outside directors have a positive association with FP and ownership concentration has an important effect on the board of directors composition.

Another recent literature stream, starting from the article of Keenan and Aggestam (2001), finds connections between CG and IC constructs. The rationale is that IC exists in the firm, and CG is accountable for IC as well as for financial capital. In detail, several empirical papers investigated a supposed association of ownership structure with IC efficiency, providing evidence of a negative effect of insider ownership on IC performance, as measured by the VAIC index (Pulic, 2000) (Saleh et al., 2009; Bohdanovich \& Urbanek, 2013; Bohdanovich, 2014). Moreover, coherently with the literature stream addressed to find an association of IC with firm performance, we believe IC, the key driver of the competitive advantage of the third millennium enterprise firm, is a variable that should be added in an holistic framework addressed to explore the association among CG with FP (Note 2). 
Only recently, researchers started to investigate the association of CG with FP, including ownership structure and IC as explanatory variables. Wang (2013), who conducted a research on Taiwanese listed firms in the information electronics industry, finds evidence of a positive relationship between variously measured IC (Tobin's Q, Knowledge Capital Earnings, VAIC) and FP and also that the characteristics of the board of directors are correlated with the valuation of IC. The same positive association of CG with FP is highlighted by the research of Makki and Lodhi (2014) conducted on Pakistan listed firms using structural equation modeling based on partial least squares, and by the research of Bambang et al. (2015) on Indonesian listed companies, also finding a different effect of managerial ownership, which moderates the relation between CG and FP with respect to the institutional ownership.

As regards Italy, the researches of Celenza \& Rossi (2013) could not provide an unequivocal association of ownership structure, board composition, IC with FP, leaving room to deepen the analysis in a context in which closely held firms are the dominant CG model (Baglioni \& Colombo, 2013).

In their conclusions, Celenza and Rossi (2013) stress their results need further study in future to understand better the nature of this complex relationship. Our paper therefore takes up this challenge, by investigating the complex relationships among ownership concentration (OC) structure, IC and FP within the Italian context including the board of directors (measured in terms of board composition) as a key explicative variable of the performance variations.

On the basis of the above literature, we formalize the three subsequent research hypotheses:

$\mathrm{H} 1$ : the $\mathrm{CG}$ is associated with the FP

$\mathrm{H} 2$ : the $\mathrm{CG}$ and the $\mathrm{OC}$ are associated with the FP

$\mathrm{H} 3$ : the $\mathrm{CG}$, the $\mathrm{OC}$, and the IC are associated with the FP

\section{Methodology: The Regression Models and the Measurement of the Variables}

The methodology employed to verify the research hypotheses was the econometric technique of OLS regressions on pooled data (POLS), that could be used in case of non-existence of individual effects (time invariant characteristics that could be peculiar to each company), revealed in our implementing a poolability test.

From a conceptual point of view, it is plausible to accept that at individual level there are no effects related to CG mechanisms, as most CG items remain unchanged for long periods of time. Brown et al. (2011) refer to this property as "stickiness".

In order to overcome the econometric problem, often related to the OLS estimates, of the heteroscedasticity of residuals, we correct our estimates by using standard errors robust to heteroscedasticity (Woolridge, 2009).

\subsection{Searching for an Association of Board Composition with Firm Profitability}

To test research hypothesis $\mathrm{H} 1$ the following model was used (1):

$$
R O A_{i t}=\alpha_{0}+\alpha_{1} I D_{i t}+\alpha_{2} N O M_{i t}+\alpha_{3} E D_{i t}+\alpha_{4} F S_{i t}+\alpha_{5} L_{i t}+\varepsilon_{i t}
$$

Where:

ROA $=$ Return on Assets, proxy of FP.

ID $=$ Independent directors.

$\mathrm{NOM}=$ nominee directors.

$\mathrm{ED}=$ Executive directors.

FS $=$ The dimension of the firm (firm size).

$\mathrm{L}=$ the level of firm indebtedness (Leverage).

The FP in the research was proxied by the accounting FP measure of ROA (return on assets) given by the ratio between net income and total net assets. The choice is justified by the consideration that in the article we are interested in measuring firm efficiency in using its resources and a profit measure like ROA demonstrating the efficiency of the firm's operations (Masa'deh et al., 2015), ideally complementing the measurement of IC, measured by an index to assess the firm's capability to employ its IC. Coherently with Joh (2003), in our article we use accounting measures of FP as they are not affected by market inefficiency, but are more directly concerned with firm's survival and profitability than market measures and they are available for both listed and unlisted firms. Moreover, among accounting-based measures, ROA is the preferred ratio when the relationship between CG and FP is investigated (Hutchinson \& Gul, 2004; Mashayekhi \& Bazazb, 2008; Nuryanah \& Islam, 
2011; Al-Matari et al., 2014) and it is considered one of the most relevant accounting measures (Aliabadi et al., 2013). In fact, ROA is a better metric of financial performance than income statement profitability measures like return on sales (ROS) or ROE, as it shows how productive the firm's total assets are in producing profits (Hagel III et al., 2010; Masa'deh et al., 2015).

$\mathrm{CG}$ in the research is proxied by the board of directors independence. The equation includes three proxies for the board composition: the executive directors (ED); the non-executive but non independent directors, elected with the controlling shareholder votes (NOM) and the non-executive and independent directors, elected without the controlling shareholders votes (ID). ED and NOM are calculated as the proportion of total directors; instead, ID is calculated in a more complex way. Coherently with Bozcuk (2011) and Fracassi and Tate (2012), ID was measured for each sampled firm using the number of independent directors on the board and their proportion in terms of representation on the board. The two variables were combined in a dummy variable equal to 1 when there are at least two independent directors on the board and contemporaneously one third of the board is made up of independent directors, as defined in the Italian Code of Conduct (joint independence). The choice to derive the criteria for measuring independence exogenously from the Code of Conduct provides some comfort that the results obtained in the empirical researches are not driven by the problems associated with endogeneity.

Control variables are used to control for firm specific characteristics because the inclusion of the control factors reduces the risk of model misspecification due to missing variables. As control variables, coherently with the previous studies in the CG-FP literature, the firm size and leverage variables were added to the model (Joh, 2003; Vo \& Nguyen, 2014; Acero Fraile \& Alcaide Fradejas, 2014). Firm size is also supposed to affect the board composition (Zhara \& Pearce II, 1989). We use a natural log transformation of total sales as a measure of firm size in order to eliminate scale effects (Brealey et al., 2007). Moreover, leverage is likely to affect CG, as debt holders can control management actions (Jensen \& Meckling, 1976; Stiglitz, 1985; Short \& Keasey, 1999; Weir et al., 2002). The ownership structure can be influenced by the debt structure (Jensen, 1989; Sun et al., 2015). Moreover, a firm with increased debt can limit its investment in R\&D, and threaten IC development and FP (Ho \& Williams, 2003).

\subsection{Including in the Research Framework the Ownership Structure and the Intellectual Capital Efficiency}

To test hypothesis $\mathrm{H} 2$, the following model was employed:

$$
R O A_{i t}=\alpha_{0}+\alpha_{1} I D_{i t}+\alpha_{2} N O M_{i t}+\alpha_{3} E D_{i t}+\alpha_{4} O C_{i t}+\alpha_{5} F_{i t}+\alpha_{6} L_{i t}+\varepsilon_{i t}
$$

Where:

$\mathrm{OC}=$ ownership concentration.

As revealed in the literature section, the OC is related to the FP (Perrini et al., 2008; Barontini \& Caprio, 2006), to the board of directors (Aceiro Fraile \& Alcade Fradejas, 2014) and to the IC (Bodhanowicz \& Urbanek, 2013; Bodhanowicz, 2014). In the article, OC is measured by the sum of the $\%$ of equity holdings equal to, or above, 2 percentage and it is used to represent total ownership concentration, coherently with Acero and Alcalde Fradejas (2014), García-Meca and Sanchéz-Ballesta (2011), Kapapoulos and Lazaretou (2007). The choice of measuring OC with this variable allows for measuring it exogenously from the Borsa Italiana, so providing some comfort that the results obtained in the empirical researches are not driven by the problems associated with endogeneity (Note 3).

In accordance with the agency theory, we hypothesize a high concentration of ownership can worsen the FP, shareholders being likely to pursue their own interests expropriating the minority shareholder interests (expropriation hypothesis) (Lefort \& Urzúa, 2008; Alipour, 2013).

To test hypothesis $\mathrm{H} 3$, the following model was employed:

$$
R O A_{i t}=\alpha_{0}+\alpha_{1} I D_{i t}+\alpha_{2} N O M_{i t}+\alpha_{3} E D_{i t}+\alpha_{4} O C_{i t}+\alpha_{4} V A I C_{i t}+\alpha_{6} F_{i t}+\alpha_{7} L_{i t}+\varepsilon_{i t}
$$

Where:

VAIC $=$ proxy of IC.

A detailed description of the IC measurement methods goes beyond the scope of this article; we focus on the VAIC $^{\text {TM }}$ method (Pulic, 1998, 2000, 2004) as it is the method used in this paper to measure a firm's ability to create value by using its tangible and intangible resources efficiently. VAIC ${ }^{\mathrm{TM}}$ has become the most used IC index for comparison of firm performance despite its main limitations: $\mathrm{HC}$ and $\mathrm{SC}$ being calculated derivatives of each other, human capital being the main focus of the method, VAIC ${ }^{\text {TM }}$ not measuring human capital, but just the use of human capital, IC measures being accounting measures derived from company accounts, and, not least, the value added measure being problematic, as it varies considerably in structure among different sectors 
and can be calculated using different configurations (Ståhle et al., 2011; Laise \& Iazzolino, 2013). VAIC ${ }^{\mathrm{TM}}$ is the most-used IC index as it makes use of financially oriented, audited and published data to assign an economic value to the components of IC (Silvestri \& Veltri, 2014).

As a recent meta-analysis provides evidence of the more significant association of VAIC ${ }^{\mathrm{TM}}$ with $\mathrm{FP}$ when VAIC $^{\mathrm{TM}}$ is articulated into its three components (Veltri, 2012), we run the regression considering the single VAIC $^{\mathrm{TM}}$ components (model $3 \mathrm{~b}$ ).

$$
R O A_{i t}=\alpha_{0}+\alpha_{1} I D_{i t}+\alpha_{2} N O M_{i t}+\alpha_{3} E D_{i t}+\alpha_{4} O C_{i t}+\alpha_{5} H C E_{i t}+\alpha_{6} S C E_{i t}+\alpha_{7} C E E_{i t}+\alpha 8 F i t+\alpha_{9} L_{i t}+\varepsilon_{i t}
$$

Where:

HCE $=$ Human Capital efficiency.

$\mathrm{SCE}=$ Structural Capital efficiency.

$\mathrm{CEE}=$ Capital Employed efficiency.

To calculate the variables for the VAIC ${ }^{\mathrm{TM}}$ calculation, we need to calculate the value added. Consistently with Rihai-Belkaoui (2003) and Ho and Williams (2003), we make reference to the Net Value Added configuration (Note 4).

Table 1 presents the description and measurement of all variables included in models 1,2 and 3.

Table 1. Variable definitions

\begin{tabular}{|c|c|c|}
\hline Variable & & Measurement \\
\hline Return on assets & ROA & Net income /total assets \\
\hline Independent directors & ID & $\begin{array}{l}1=\text { joint independence (contemporaneously two independent directors and one } \\
\text { third of the board are independent) } \\
0=\text { otherwise }\end{array}$ \\
\hline Nominee directors & NOM & Number of nominee non-executive directors/total number of directors \\
\hline Executive directors & ED & Number of executive directors/total number of directors \\
\hline Ownership Concentration & $\mathrm{OC}$ & Sum of the percentage of equity holdings equal to, or above, $2 \%$ \\
\hline Capital Employed Efficiency & CEE & $\mathrm{CEE}=\mathrm{VA} / \mathrm{CE}$ \\
\hline Human Capital Efficiency & $\mathrm{HCE}$ & $\mathrm{HCE}=\mathrm{VA} / \mathrm{HC}$, where $\mathrm{HC}$ is measured by salaries and wages \\
\hline Structural Capital Efficiency & SCE & $\begin{array}{l}\mathrm{SCE}=\mathrm{SC} / \mathrm{VA} \\
\text { where } \mathrm{SC}=\mathrm{VA}-\mathrm{HC}\end{array}$ \\
\hline Capital Efficiency & VAIC & $\mathrm{CEE}+\mathrm{HCE}+\mathrm{SCE}$ \\
\hline Leverage & $\mathrm{L}$ & (Total debt / Total shareholder equity) \\
\hline Firm size & FS & Natural log of annual sales \\
\hline
\end{tabular}

\section{Sample Selection}

In the article we analyze the non-financial firms listed on the Italian Stock Exchange in the period 2008-2010.

Italy was chosen because, in terms of board features, the Italian corporate system offers a relatively unique environment for assessing the effect of CG mechanisms on a firm's VA efficiency. The Italian market is a less developed one in an equity context than the U.S. and the British markets (Allegrini \& Greco 2013). The Italian manufacturing system is characterized, with few exceptions, by small- and medium-sized firms, in which banks take an active role as credit lender (bank-centered market). Listed firms are mainly family owned, with a high ownership concentration. Moreover, even though it has grown in recent decades, the number of listed companies remains exiguous with respect to the benchmark markets. There are also a significant number of state-owned companies. Compared to the US and the UK, the market, the institutional investors, the financial institutions and the regulators are less active as corrective mechanisms against management entrenchment and corporate failure; this makes the role of internal governance mechanisms, such as the board of directors, relevant in Italy. The Italian stock exchange is characterized by companies with large controlling shareholders, who can influence the board and the committees' agenda, so the agency problem in Italy is not one between ownership and control, rather, it is a problem between majority and minority shareholders, whose interests need to be legally protected (Brealey et al., 2007; Allegrini \& Greco 2013; Baglioni \& Colombo, 2013; Perrini et al., 2008).

The initial number of companies (293) is subject to a reduction due to the incompleteness of data. The criteria for the sample selection were the following: 
1) We included the firms listed in the three-year period 2008-2010;

2) We took into consideration only those firms not banned by regulators;

3) We eliminated observations relating to listed firms in which one or more key variables were missing.

The final sample is made up of 179 firms (537 observations as shown in Table 2).

Table 2. The sample selection process

\begin{tabular}{ll}
\hline Sample selection process & Number of firms \\
\hline Total firms listed in the Italian Stock Exchange Firms belonging to the financial sector & 293 \\
Total non-financial listed firms & $56)$ \\
Firms with incomplete data & 237 \\
Final sample & $(58)$ \\
& 179 \\
Observation (179 for three years) & 537 \\
\hline
\end{tabular}

Once the sample was defined, we proceeded with the gathering of the secondary financial and accounting data (ROA) through the database Datastream to calculate the VA firm's efficiency in using its resources and for the control variables. Conversely, data for the corporate board features were hand-collected, the CG annual reports being available on the companies' web sites. The CG data was collected separately and compared by the authors, who conducted a data reliability analysis by sample verification. Information on ownership structure was retrieved by Consob (Italian Securities Exchange Commission) web site for 2008-2010.

\section{Ownership Structure and Corporate Governance of Italian Listed Firms: A Descriptive Analysis}

The characteristics of the overall sample in the period 2008-2010 are shown in table 3 . The sample consists of 537 observations for 179 companies (Table 3).

Lipton and Lorsch (1992), in their study, suggest that a board composed of around 8 or 9 members is ideal from a monitoring perspective, so the figures reported for the present sample would appear to be approximately closer to their suggested target. Moreover, independents make up more than a third of all board members $(39 \%)$.

Table 3. Descriptive statistics

\begin{tabular}{llll}
\hline Variable & Full sample & Median & Standard deviation \\
\hline Ownership first shareholder (\%) & 47.31 & 52.06 & 18.91 \\
Ownership second shareholder (\%) & 8.42 & 6.77 & 6.73 \\
Ownership third shareholder (\%) & 4.36 & 3.35 & 4.25 \\
Ownership fourth shareholder (\%) & 2.69 & 2.25 & 2.83 \\
Ownership fifth shareholder (\%) & 1.38 & 0 & 2.28 \\
Ownership 5sh (\%) & 63.87 & 66.33 & 15.21 \\
Ownership concentration (\%) & 66.11 & 67.82 & 14.90 \\
Number of relevant shareholder & 4.28 & 4 & 2.54 \\
Firm Size & 12.69 & 12.44 & 1.82 \\
Board Size (number) (independent + nominee + executive) & 9.53 & 9 & 3.11 \\
Independent director (number) & 3,68 & 3 & 2.17 \\
Joint independence & 0.59 & 1 & 0.49 \\
Executive director (number) & 2.82 & 3 & 1.53 \\
Nominee directors (number) & 3.03 & 2.47 \\
Leverage & 70.85 & 38.07 & 151.38 \\
ROA & 1.03 & 2.12 & 9.04 \\
VAIC & -2.56 & 0.44 & 36.57 \\
HCE & 0.25 & 0.17 & 1.11 \\
CEE & 0.03 & 0.03 & 0.13 \\
SCE & -2.84 & -0.09 & 36.55 \\
Number of observation & 537 & & \\
\hline
\end{tabular}


Table 4. Difference across concentrated and non-concentrated companies

\begin{tabular}{llll}
\hline Variable & $\begin{array}{l}\text { Concentrated companies } \\
\text { (ownership } \mathbf{5 0 \% )}\end{array}$ & $\begin{array}{l}\text { Non Concentrated companies } \\
\text { (ownership } \leq \mathbf{5 0} \%)\end{array}$ & P-value diff. * \\
\hline Ownership first shareholder (\%) & 52.70 & 23.09 & 0.00 \\
Ownership second shareholder (\%) & 8.73 & 6.99 & 0.31 \\
Ownership third shareholder (\%) & 4.38 & 4.22 & 0.46 \\
Ownership fourth shareholder (\%) & 2.26 & 2.69 & 0.08 \\
Ownership fifth shareholder (\%) & 1.29 & 2.81 & 0.02 \\
Ownership 5sh (\%) & 69.33 & 38.82 & 0.00 \\
Ownership concentration (\%) & 71.01 & 43.58 & 0.00 \\
Number of relevant shareholder & 4 & 4 & 0.00 \\
Firm Size & 12.55 & 13.30 & 0.02 \\
Board Size (number) & 9.34 & 10.43 & 0.00 \\
Independent director(number) & 3.5 & 4.51 & 0.00 \\
Joint Independence & 0.58 & 0.68 & 0.04 \\
Executive director (number) & 2.95 & 2.22 & 0.00 \\
Nominee directors (number) & 2.87 & 3.70 & 0.15 \\
Leverage & 72.25 & 64.44 & 0.88 \\
ROA & 1.28 & -0.14 & 0.29 \\
VAIC & -3.05 & -0.33 & 0.29 \\
HCE & 0.25 & 0.23 & 0.49 \\
CEE & 0.03 & 0.03 & 0.81 \\
SCE & -3.33 & -0.60 & 0.18 \\
Number of observation & 310 & 227 & \\
\hline
\end{tabular}

\section{Main Findings}

A Pearson correlation analysis is performed on all variables included in the models, to check for the degree of multicollinearity among the variables, which can cause bias in the regression coefficients. The results are shown in table 5, this provides pairwise correlation among the main variables considered in the analysis.

Table 5. Correlation matrix

\begin{tabular}{|c|c|c|c|c|c|c|c|c|c|c|c|}
\hline & ED & ID & NOM & ROA & FS & $\mathbf{L}$ & OC & CEE & SCE & HCE & VAIC \\
\hline ED & 1 & & & & & & & & & & \\
\hline ID & $-0.14 * * *$ & 1 & & & & & & & & & \\
\hline NOM & $-0.33 * * *$ & $-0.33 * * *$ & 1 & & & & & & & & \\
\hline ROA & $0.14 * * *$ & 0.01 & $-0.08^{* *}$ & 1 & & & & & & & \\
\hline FS & -0.02 & $0.25 * * *$ & $0.19 * * *$ & $0.34 * * *$ & 1 & & & & & & \\
\hline \multirow[t]{2}{*}{$\mathbf{L}$} & -0.06 & 0.07 & 0.05 & $-0.08^{* *}$ & & 1 & & & & & \\
\hline & & & & & $0.15^{* * *}$ & & & & & & \\
\hline OC & $0.18^{* * *}$ & $-0.17 * * *$ & -0.002 & 0.05 & $-0.19 * * *$ & -0.00 & 1 & & & & \\
\hline \multirow[t]{2}{*}{ CEE } & $0.14 * * *$ & 0.03 & -0.01 & $0.78^{* * *}$ & & 0.03 & -0.00 & 1 & & & \\
\hline & & & & & $0.37 * * *$ & & & & & & \\
\hline SCE & -0.00 & 0.04 & -0.04 & -0.02 & -0.02 & 0.03 & -0.02 & -0.03 & 1 & & \\
\hline \multirow[t]{2}{*}{ HCE } & 0.03 & $0.08^{* * *}$ & 0.02 & $0.59^{* * *}$ & & 0.03 & -0.00 & $0.66^{* * *}$ & -0.00 & 1 & \\
\hline & & & & & $0.49 * * *$ & & & & & & \\
\hline VAIC & 0.00 & 0.04 & -0.04 & -0.00 & -0.00 & 0.03 & -0.00 & -0.00 & $0.99^{* * *}$ & 0.03 & 1 \\
\hline
\end{tabular}

$* * *, * *=$ significant at the 5 and $10 \%$ level respectively.

In the Pearson correlations reported in table 6 , the coefficients do not exceed 0.8 , which is used as an indicator of serious multicollinearity (Gujarati, 1992). Only the SCE variable and VAIC variable are highly correlated, but not used in the same model, thus not provoking multicollinearity problems. The independent variables are not correlated. 


\subsection{Main Findings of the Model 1 and 2}

Table 6 illustrates the results of model 1, which as for all the other models is significant at $10 \%$ confidence level. The dependent variable is ROA.

Table 6. Regression results of the model 1

\begin{tabular}{llll}
\hline Variable & $\begin{array}{l}\text { Model 1 } \\
\text { Coefficient }\end{array}$ & Beta (Note 5) & VIF \\
\hline Intercept & -22.75 & & \\
& $(0.000)$ & -0.136 & 1.40 \\
ID & -2.50 & & 1.50 \\
& $(0.005)$ & -0.175 & 1.25 \\
NOM & -0.64 & & \\
& $(0.001)$ & 0.068 & 1.21 \\
ED & 0.40 & & 1.03 \\
FS & $(0.067)$ & 0.420 & \\
& 2,09 & & Mean VIF 1.28 \\
L & $(0.000)$ & -0.117 & \\
& -0.007 & & \\
$\mathrm{R}^{2}$ & $(0.017)$ & & \\
Adj $\mathrm{R}^{2}$ & 0.1726 & & \\
F-Test & 0.1648 & & \\
& 12.20 & & \\
\hline
\end{tabular}

Notes. 2 tailed p-value are given in brackets.

The findings evidence that non-executive directors (NED), both independent and nominee directors, negatively affect firm performance. The result also implies NED are generally not effective monitors in a high ownership concentration context like Italy. This result is not in line with the agency theory, but is coherent with the results of Hemalin and Weisback (1991), Agrawal and Knoeber (1996), Bhagat and Black (1999), Erickson et al. (2005) and also with the findings of Baglioni and Colombo (2013), focused within the Italian context. From the findings, it appears FP is negatively affected by the NEDs, while being positively affected by the EDs. A possible explanation is EDs contribute to the efficiency of the decision process by bringing specific knowledge. More relevant for our research is the issue of the NEDs and of their effect on FP. The puzzling result can be explained considering NEDs play mainly a monitoring role, which can reduce the speed and efficiency of the board decision-making process. Also other two theoretical interpretations of the negative association between NEDs and FP can be suggested. The first is linked to the consideration that listed firms, to accomplish the recommendations introduced at national level to promote "good governance" (such as the Code of Conduct), could feel forced to introduce an inefficiently large independent component in their boards. The second reason is related to reputational concerns: even in the absence of explicit regulatory constraints, some companies could feel forced to sub-optimally add independent directors giving them a formal role and not a substantial one.

As regards the control variable, size of the firm, the results evidence the existence of a positive association between firm size and FP, coherently with Quang and Xin (2014), Alimehmeti and Paletta (2012), Lefort and Urzúa (2008); Reyna et al. (2012), Alipour (2013), Kamis et al. (2015), Wang (2013); Bodhanowicz and Urbanek (2013), Bodhanowicz (2014), which is consistent with the assumption that large firms can access funds more easily and are able to create entry barriers. The other control variable, leverage, shows a negative and significant relationship with FP, coherently with Titman and Wessels (1988), Rajan and Zingales (1995), Zeitun and Tian (2007), Kapapoulos and Lazaretou (2007), Quang and Xin (2014), and consistently with the pecking order theory, where firms use internally generated funds as the first option to finance projects before resorting to debt.

Table 7 illustrates the results of model (2). The dependent variable is ROA. 
Table 7. Regression results model 2

\begin{tabular}{llll}
\hline Variable & $\begin{array}{l}\text { Model } 2 \\
\text { Coefficient }\end{array}$ & Beta & VIF \\
\hline Intercept & -27.60 & & \\
& $(0.000)$ & & 1.41 \\
ID & -2.34 & -0.128 & \\
& $(0.009)$ & & 1.50 \\
NOM & $-0.66(0.001)$ & -0.181 & 1.29 \\
ED & 0.28 & 0.048 & 1.09 \\
& $(0.174)$ & & \\
OC & 0.000 & 0.100 & 1.25 \\
& $(0.064)$ & & 1.03 \\
FS & 2,18 & 0.438 & \\
& $(0.000)$ & & \\
L & -0.007 & -0.120 & \\
& $(0.008)$ & & \\
$\mathrm{R}^{2}$ & 0.1820 & & \\
Adj $\mathrm{R}^{2}$ & 0.1727 & & \\
F-Test & 10.53 & & \\
& $(0.000)$ & & \\
\hline
\end{tabular}

Notes. 2 tailed p-value are given in brackets.

The inclusion of the OC variable does not affect the sign and the significance of the board composition and control variables. In line with most of the studies addressed to test a relationship between OC and FP, the findings provide evidence of a positive and significant association of the two variables. Theoretically speaking, the results are coherent with the monitoring hypothesis, where a higher concentration of ownership gives large shareholders stronger incentives and greater power at lower cost to monitor management ( $\mathrm{Hu}$ and Izumida, 2008).

Our results are in line with the empirical results of studies focused on Continental Europe and East Asian economies, likely to have a high concentration ownership context (Kapapoulos \& Lazaretou, 2007; Hu \& Izumida, 2008) and above all with the other studies conducted within the Italian context (Perrini et al., 2008; Alimehmeti \& Paletta, 2012; Celenza \& Rossi, 2013). This evidence confirms large shareholders are better monitors than dispersed shareholders (La Porta et al., 2000; Perini et al., 2008) and ownership concentration is not detrimental to FP instead, in an Italian-like environment, it affects FP positively. In other words, the results confirm the agency theory that higher OC increases shareholder power and control, allowing managers and shareholders' interests to be aligned, consequently increasing FP.

\subsection{Main Findings of Model $3 a$ and $3 b$}

Table 8 illustrates the results of model $3 \mathrm{a}$ and $3 \mathrm{~b}$. The dependent variable is ROA.

Models $3 \mathrm{a}$ and $3 \mathrm{~b}$ include IC, as measured by VAIC, by allowing both the measurement of IC by a single index, and the measurement of IC articulating it into VAIC sub-components. The inclusion of VAIC in model 3a is not significant, not surprisingly as many studies re-elaborated also in a meta-analysis (Veltri, 2009) of the relationship between IC and FP show the better explicative power of the VAIC sub-components instead of VAIC index. Thus, if we focus on model $3 \mathrm{~b}$, we can observe all variables maintain their sign and significance with respect to models 1 and 2, except for the executive directors. As regards the VAIC components, we can notice they are significant and positively associated with FP, the efficiency of human capital (HCE) and the capital employed efficiency (CEE), while the relationship between the efficiency of structural capital (SCE) and the FP is not negative but not significant. The results are in line with the majority of studies investigating the relationship between VAIC components and FP, which provide evidence of a better explicative power of the HCE component in explaining performance variations (Veltri, 2009). In detail, HCE and SCE are constructed in a complementary way and this is likely to affect the sign and significance of the two variables (see Silvestri \& Veltri, 2014; Sthale et al., 2011; Iazzolino \& Laise, 2013).

Summarizing, we can observe the $\mathrm{R}^{2}$ largely increases with respect to the other models and the $\mathrm{F}$ value (which measures the conjoint significant of the coefficients of the variables included within the model records a strong 
improvement with respect to the previous model. From an economic point of view, these results show that the board composition, ownership concentration and the efficiency of intellectual capital increases firm profitability, as measured by ROA.

Table 8. Regression results model 3a and $3 \mathrm{~b}$

\begin{tabular}{|c|c|c|c|c|c|c|}
\hline \multirow[b]{2}{*}{ Variable } & \multirow[b]{2}{*}{ Coefficient } & \multicolumn{2}{|c|}{ Model 3a } & \multirow[b]{2}{*}{ Coefficient } & \multicolumn{2}{|c|}{ Model 3b } \\
\hline & & Beta & VIF & & Beta & VIF \\
\hline \multirow[t]{2}{*}{ Intercept } & -27.59 & & & -6.56 & & \\
\hline & $(0.000)$ & & & $(0.023)$ & & \\
\hline \multirow[t]{2}{*}{ ID } & -2.36 & -0.13 & 1.41 & -1.30 & -0.071 & 1.42 \\
\hline & $(0.009)$ & & & $(0.022)$ & & \\
\hline \multirow[t]{2}{*}{ NOM } & -0.66 & -0.18 & 1.50 & -0.44 & -0.120 & 1.52 \\
\hline & $(0.001)$ & & & $(0.000)$ & & \\
\hline \multirow[t]{2}{*}{ ED } & 0.28 & 0.05 & 1.29 & -0.112 & -0.019 & 1.31 \\
\hline & $(0.174)$ & & & $(0.501)$ & & \\
\hline \multirow[t]{2}{*}{$\mathrm{OC}$} & 0.06 & 0.10 & 1.09 & 0.040 & 0.066 & 1.09 \\
\hline & $(0.056)$ & & & $(0.096)$ & & \\
\hline \multirow[t]{2}{*}{ VAIC } & 0.00 & 0.00 & 1.00 & & & \\
\hline & $(0.792)$ & & & & & \\
\hline \multirow[t]{2}{*}{ CEE } & & & & 46.95 & 0.671 & 1.83 \\
\hline & & & & $(0.000)$ & & \\
\hline \multirow[t]{2}{*}{$\mathrm{HCE}$} & & & & 0.911 & 0.111 & 2.04 \\
\hline & & & & $(0.017)$ & & \\
\hline \multirow[t]{2}{*}{ SCE } & & & & -0.000 & -0.003 & 1.01 \\
\hline & & & & $(0.743)$ & & \\
\hline \multirow[t]{2}{*}{ Firm size } & 2.18 & 0.43 & 1.25 & 0.49 & 0.099 & 1.66 \\
\hline & $(0.000)$ & & & $(0.001)$ & & \\
\hline \multirow[t]{2}{*}{ Leverage } & -0.007 & -0.12 & 1.03 & -0.006 & -0.104 & 1.03 \\
\hline & $(0.008)$ & & & $(0.008)$ & & \\
\hline $\mathrm{R}^{2}$ & 0.1820 & & & 0.6363 & & \\
\hline $\operatorname{Adj} R^{2}$ & 0.1712 & & & 0.6307 & & \\
\hline \multirow[t]{2}{*}{ F-Test } & 9.09 & & & 22.09 & & \\
\hline & $(0.000)$ & & & $(0.000)$ & & \\
\hline
\end{tabular}

Notes. 2 tailed p-value are given in brackets.

\section{Conclusions}

The aim of the paper was to contribute to the debate on the nature of the relationship between CG and FP by trying to overcome one of the limits attributed by the literature to previous empirical studies: the possible bias in the regression coefficients deriving from the use of a research framework not including variables likely to affect both CG and FP. Our main contribution therefore was to design a research framework to unveil the association of CG with FP including two variables the literature showed to affect CG and FP: OC and IC. By examining the previous literature, and its mixed results, we chose the variables to use in our research framework (board composition as proxy for $\mathrm{CG}$, ROA as proxy for FP, VAIC as proxy for IC, block holder equal or superior to $2 \%$ as proxy of OC).

The findings provide evidence of a better superior explicative power of the proposed model inclusive of OC and VAIC components with respect to the other models which do not include them.

The findings of the paper therefore add knowledge to the relationship between CG and FP, by confirming the existence of a positive relationship in the context of a continental European capital market, which is less investigated than the US and UK markets, in a high concentrated ownership context, also taking into consideration the role played by IC for the performance variations.

The main limit of the paper lies in the data sample used which covers a comprehensive but geographically limited data set: the Italian context. A future research direction could be to replicate the estimates using a broader sample of firms from other European capital markets, to compare the results obtained in the different contexts. 
Other future research directions could be to progress the regression model, for instance by including industry dummies to account for effects due to the nature of firm industry, to take into consideration the year and time effect, to measure the main variables (FP, IC, CG and OC) with different proxies. In detail, there is room to improve the $\mathrm{OC}$ variable, by considering its multiple dimensions (managerial, foreign, institutional). Among these, a peculiar importance is assumed by family ownership, Italy being characterized by a prevalence of family firms. A future research direction could explore this aspect, by examining a possible relation between the owner identity and firm performance. Additional suggestions for future research include the development of a generalized non-linear model specification for OC, which takes into account its possible endogeneity.

\section{Acknowledgments}

We are grateful to the participants of the SIDREA International Workshop (SIW) "Innovations in corporate governance and performance management" for useful comments and suggestions. We would also like to thank the Editors and the anonymous reviewer, whose many invaluable comments improved the substance of the paper. Although the paper is the result of an equal joint effort by the two authors, their primary individual contributions are reflected in the following sections of the paper: Stefania Veltri: 1, 2, 3, 3.2,4, 6.1; Romilda Mazzotta: 3.1, 5, $6,6.2,7$.

\section{References}

Acero, F. I., \& Alcade, F. N. (2014). Ownership structure and board composition in a high ownership concentration context. European Management Journal, 20, 646-657. http://dx.doi.org/10.1016/j.emj.2013.10.003

Acero, I., \& Alcade, N. (2016). Controlling shareholders and the composition of the board: special focus on family firms. Review of Managerial Science, 10, 61-83. http://dx.doi.org/10.1007/s11846-014-0140-x

Agrawal, A., \& Knoeber, C. R. (1996). Firm Performance and Mechanisms to Control Agency Problems Between Manager and Shareholders. Journal of Financial and Quantitative Analysis, 31, 377-89. http://dx.doi.org/10.2307/2331397

Aliabadi, S., Dorestani, A., \& Balsara, N. (2013). The most value relevant accounting performance measure by industry. Journal of Accounting and Finance, 13(1), 22-35.

Alimehmeti, G., \& Paletta, A. (2012). Ownership concentration and effects over firm performance: evidences from Italy. European Scientific Journal, 8(22), 39-49.

Alipour, M. (2013). An investigation of the association between ownership structure and corporate performance. Management Research Review, 36(11), 1137-1166. http://dx.doi.org/10.1108/MRR-08-2012-0188

Al-Matari, E. M., Al-Swidi, A. K., \& Fadzil, F. H. B. (2014), The Measurements of Firm Performance's Dimensions. Asian Journal of Finance \& Accounting, 6(1), 24-49. http://dx.doi.org/10.5296/ajfa.v6i1.4761

Allegrini, M., \& Greco, G. (2013). Corporate boards, audit committees and voluntary disclosure: evidence from Italian Listed companies. Journal of Management and Governance, 17(1), 187-216. http://dx.doi.org/10.1007/s10997-011-9168-3

Anderson, R., \& Reeb, D. (2004). Board composition: balancing family influence in S\&P 500 firms. Administrative Science Quarterly, 49, 209-237.

Bachiller, P., Giorgino, M. C., \& Paternostro, S. (2016). Influence of board of directors on firm performance: Analysis of family and non-family firms. International Journal of Disclosure and Governance, 12, 230-253. http://dx.doi.org/10.1057/jdg.2014.2

Baglioni, A., \& Colombo, L. (2013). The efficiency view of corporate boards: Theory and evidence, Applied Economics, 45, 497-510. http://dx.doi.org/10.1080/00036846.2011.605764

Bambang, B. S., Mukhtaruddin, A. H., \& Rahmah, F. (2015). Intellectual capital, firm value and ownership structure as moderating variable: Empirical study on banking listed in Indonesia Stock Exchange period 2009-2012. Asian Social Science, 11(16), 148-159.

Barontini, R., \& Caprio, L. (2006). The effect of family control on firm value and performance: evidence from continental Europe. European Financial Management, 12(5), 689-723. http://dx.doi.org/10.1111/j.1468-036X.2006.00273.x

Bhagat, S., \& Black, B. (1999). The Uncertain Relationship between Board Composition and Firm Performance, Business Lawyer, 54, 921-963. 
Bohdanowicz, L. (2014). Managerial Ownership and Intellectual Capital Efficiency: Evidence from Poland. China-USA Business Review, 13(10), 626-635.

Bohdanowicz, L., \& Urbanek, G. (2013). The Impact of Ownership Structure on Intellectual Capital Efficiency: Evidence from Polish Emerging Market (December 27, 2013). Retrieved from http://ssrn.com/abstract=2372412

Bozcuk, A. E. (2011). Performance effects of outside directors on corporate boards. International Journal of Business and Social Science, 2(20), 80-84.

Brealey, R. A., Myers, S. C., Allen, F., \& Sandri, S. (2007). Principi di Finanza Aziendale (Principles of Corporate Finance). V edition, Milan: McGraw-Hill.

Brown, P., Beekes, W., \& Verhoeven, P. (2011). Corporate governance, accounting and finance: a review. Accounting and Finance, 51, 96-172. http://dx.doi.org/10.1111/j.1467-629X.2010.00385.x

Celenza, D., \& Rossi, F. (2013). Ownership concentration, intellectual capital, and firm performance: evidence from Italy. China-USA Business Review, 12(12), 1157-1174.

Conheady, B., McIlkenny, P., Kwaku, K. O., \& Pignatel., I. (2015). Board effectiveness and firm performance of Canadian listed firms. The British Accounting Review, 47(3), 290-303. http://dx.doi.org/10.1016/j.bar.2014.02.002

Dahya, J., \& McConnell, J. (2007) Board composition, corporate performance and the Cadbury committee recommendation. Journal of Financial and Quantitative Analysis, 42(3), 535-564. http://dx.doi.org/10.1017/S0022109000004099

Edvinsson, L., \& Malone, M. S. (1997). Intellectual capital-realizing your company's true value by finding its hidden brainpower. New York: Harper Business Publisher.

Erickson, J., Park, Y.W., Reising, J. \& Shin H.H. (2005). Board composition and firm value under concentrated ownership: The Canadian evidence. Pacific-Basin Finance Journal, 13, 387-410. http://dx.doi.org/10.1016/j.pacfin.2004.11.002

Fama, E. F., \& Jensen, M. C. (1983). Separation of ownership and control. Journal of Law and Economics, 25(2), 301-325. http://dx.doi.org/10.1086/467037

Fracassi, C., \& Tate, G. (2012). External networking and internal firm governance. The Journal of Finance, LXVII(1), 153-194. http://dx.doi.org/10.1111/j.1540-6261.2011.01706.x

García-Meca, E., \& Sánchez- Ballesta J. P. (2011). Firm value and ownership structure in the Spanish capital market. Corporate Governance: The international journal of business in society, 11(1), 41-53. http://dx.doi.org/10.1108/14720701111108835

Gentry, R. J., \& Shen, W. (2010). The relationship between accounting and market measures of firm financial performance: How strong is it? Journal of Managerial Issues, 22(4), 514-530.

Gujarati, D. N. (1992). Essentials of Econometrics. New York, McGraw-Hill

Hagel, III. J., Brown, J. S., \& Davison, L. (2010). The best way to measure company performance. Harvard Business Review.

Haller, A. (1997). About the decision-usefulness of a value added statement as part of financial statements. Annual Congress of the European Accounting Association. Graz, $23^{\text {th }}-25^{\text {th }}$ of April.

Hermalin, B. E., \& Weisbach, M. S. (1991). The effects of board composition and direct incentives on firm performance. Financial Management, 20(4), 101-112. http://dx.doi.org/10.2307/3665716

Ho, C. A., \& Williams, S. M. (2003). International Comparative Analysis of the Association between Board Structure and the efficiency of Value Added by a Firm from its Physical Capital and Intellectual Capital Resources. The International Journal of Accounting, 38(4), 465-491. http://dx.doi.org/10.1016/j.intacc.2003.09.001

Hu, Y., \& Izumida, S. (2008). The relationship between ownership and performance: A review of theory and performance: A review of theory and evidence. International Business Research, 1(4), 72-81.

Hult, G. T. M., Ketchen, Jr. D. J., Griffith, D. A., Chabowski, B. R., Dykes, B. J., Pollitte, W. A., \& Cavusgil, S. T. (2008). An assessment of the measurement of performance in international business research. Journal of International Business Studies, 39, 1064-1080. http://dx.doi.org/10.1057/palgrave.jibs.8400398 
Hutchinson, M., \& Gull, F. (2004). Investment opportunity set, corporate governance practices, and firm $\begin{array}{lllll}\text { performance. Journal of } & \text { Corporate }\end{array}$ http://dx.doi.org/10.1016/S0929-1199(03)00022-1

Jameson, M., Prevost, A., \& Puthenpurackal, J. (2014), Controlling shareholders, board structure, and firm performance: Evidence from India. Journal of Corporate Finance, 27, 1-20. http://dx.doi.org/10.1016/j.jcorpfin.2014.04.003

Jensen, M. C., \& Meckling, W. H. (1976) Theory of the firm: Managerial behaviour, agency costs and ownership $\begin{array}{llll}\text { structure. Journal of } & \text { Financial 305-360. }\end{array}$ http://dx.doi.org/10.1016/0304-405X(76)90026-X

Joh, S. W. (2003). Corporate governance and firm profitability: evidence from Korea before the economic crisis. Journal of Financial Economics, 68, 287-322. http://dx.doi.org/10.1016/S0304-405X(03)00068-0

Kapopoulos, P., \& Lazaretou S. (2007) Corporate ownership structure and firm performance: evidence from Greek firms, Corporate Governance: An International Review, 15(2), 144-158.

Keenan, J., \& Aggestam, M. (2001). Corporate Governance and Intellectual Capital: Some conceptualisations, Corporate Governance, 9(4), 259-275. http://dx.doi.org/10.1111/1467-8683.00254

Kouki, M., \& Guizani, M. (2015). Outside directors and firm performance: The moderating effects of ownership and board leadership structure. International Business Research, 8(6), 104-116. http://dx.doi.org/10.5539/ibr.v8n6p104

La Porta, R., Lopez, F., Shleifer, A., \& Vishny, R. W. (2000). Investor protection and corporate governance. Journal of Financial Economics, 58, 3-28. http://dx.doi.org/10.1016/S0304-405X(00)00065-9

Lefort, F., \& Urzúa, F. (2008). Board independence, firm performance and ownership concentration: Evidence from Chile. Journal of Business Research, 61, 615-622. http://dx.doi.org/10.1016/j.jbusres.2007.06.036

Lipton, M., \& Lorsch, J. W. (1992). A modest proposal for improved corporate governance. The Business Lawyer, 48(1), 59-77.

Makki, M. A. M., \& Lodhi, S. A. (2014). Impact of corporate governance on intellectual capital efficiency and Pakistan Journal of Commerce and Social Science, 8(2), 305-330.

Martín-De Castro, G., Delgado-Verde, M., Navas-López, J., \& López-Sáez, P. (2011). Towards An Intellectual Capital-Based View of The Firm. Journal of Business Ethics, 98(4), 649-662. http://dx.doi.org/10.1007/s10551-010-0644-5

Masa'deh, R., Tayeh, M., Al-Jarrah, I. M., \& Tarhini, A. (2015). Accounting vs. market-based measures of firm performance related to information technology investments. International Review of Social Sciences and Humanities, 9(1), 129-145.

Mashayekhi, B., \& Bazazb, M. S. (2008). Corporate governance and firm performance in Iran, Journal of $\begin{array}{lllll}\text { Contemporary Accounting and } & \text { 156-172. }\end{array}$ http://dx.doi.org/10.1016/S1815-5669(10)70033-3

Mazzotta, R., \& Veltri, S. (2014). The relationship between corporate governance and the cost of equity capital. Evidence from the Italian stock exchange. Journal of Management and Governance, 18, 419-448. http://dx.doi.org/10.1007/s10997-012-9230-9

Meritum. (2002). Guidelines for Managing and Reporting on Intangibles. Madrid: Fundaciòn Aritel Mòvil.

Montrone, A. (2000), Il valore aggiunto nella misurazione della performance economica e sociale dell'impresa. Milan: FrancoAngeli.

Morley, M. (1979). The value added statement in Britain. The Accounting Review, 4(3), 618-629.

Muttakin, M. B., Khan, A., \& Belal, A. R. (2015). Intellectual capital disclosures and corporate governance: An empirical examination, Advances in Accounting incorporating Advances in International Accounting, 31, 219-227.

Nuryanah, S., \& Islam, S. M. N. (2011). Corporate governance and performance: Evidence from an Emerging Market. Malaysian Accounting Review, 10(1), 17-42.

Perini, F., Rossi, G., \& Rovetta, B. (2008). Does ownership structure affect performance? Evidence from the Italian market. Corporate Governance, 16(4), 312-325. http://dx.doi.org/10.1111/j.1467-8683.2008.00695.x 
Pulic, A. (1998). Measuring the Performance of Intellectual Potential in Knowledge Economy. Retrieved from http://www.vaic-on.net

Pulic, A. (2004). Intellectual capital - does it create or destroy value? Measuring Business Excellence, 8(1), 62-68. http://dx.doi.org/10.1108/13683040410524757

Pulic, A., (2000). VAIC ${ }^{\mathrm{TM}}$ - An accounting tool for IC management. International Journal of Technology Management, 20(5-8), 702-714. http://dx.doi.org/10.1504/IJTM.2000.002891

Quang, X. (2014). The Impact of Ownership Structure and Capital Structure on Financial Performance of Vietnamese Firms. International Business Research, 7(2), 64-71. http://dx.doi.org/10.5539/ibr.v7n2p64

Rajan, G. R., \& Zingales, L. (1995). What do we know about capital structure? Some evidence from international data. Journal of Finance, 50, 1421-1460. http://dx.doi.org/10.1111/j.1540-6261.1995.tb05184.x

Reed, K. K., Lubatkin, M., \& Srinivasan, N. (2006). Proposing and testing an intellectual capital-based view of $\begin{array}{llll}\text { the firm. Journal of Management Studies, } & \text { 43(4), 868-893. }\end{array}$ http://dx.doi.org/10.1111/j.1467-6486.2006.00614.x

Reyna, J. M. S. M., Vázquez, R. D., \& Valdés, A. L. (2012). Corporate governance, ownership structure and performance in Mexico. International Business Research, 5(11), 12-27. http://dx.doi.org/10.5539/ibr.v5n11p12

Richard, P. J., Devinney, T. M., Yip, G. S., \& Johnson, G. (2009). Measuring organizational performance: towards methodological best practice. Journal of Management, 35(3), 718-804. http://dx.doi.org/10.1177/0149206308330560

Rihai-Belkaoui, A. (2003), Intellectual capital and firm performance of US multinational firms: a study of the resource-based and stakeholder view. Journal of Intellectual Capital, 4(2), 215-226. http://dx.doi.org/10.1108/14691930310472839

Saleh, N. M.., Rahman, M. R. C. A., \& Hassan, M. S. (2009). Ownership Structure and Intellectual Capital performance in Malaysia. Asian Academy of Management Journal of Accounting and Finance, 5(1), 1-29.

Short, H., \& Keasey, K. (1999). Managerial ownership and the performance of firms: Evidence from the UK. Journal of Corporate Finance, 5, 79-101. http://dx.doi.org/10.1016/S0929-1199(98)00016-9

Silvestri, A., \& Veltri, S. (2014). Overcoming the additive property of value added intellectual capital (VAIC ${ }^{\mathrm{TM}}$ ) methodology. International Journal of Learning and Intellectual Capital, 11 (3), 222-243. http://dx.doi.org/10.1504/IJLIC.2014.063892

Ståhle, P., Ståhle, S., \& Aho, S. (2011). Value added intellectual coefficient (VAIC): a critical analysis. Journal of Intellectual Capital, 12(4), 531-551. http://dx.doi.org/10.1108/14691931111181715

Stiglitz, J. (1985). Credit markets and the control of capital. Journal of Money, Credit and Banking, 17, 133-152. http://dx.doi.org/10.2307/1992329

Sun, J., Ding, L., Guo, J., \& Li, Y. (2015), Ownership, Capital Structure and Financing Decision: Evidence from the UK, The British Accounting Review. http://dx.doi.org/10.1016/j.bar.2015.04.001

Titman, S., \& Wessels, R. (1988). The determinants of capital structure choice. Journal of Finance, 43, 1-19. http://dx.doi.org/10.1111/j.1540-6261.1988.tb02585.x

Veltri S. (2009). The impact of Intellectual Capital measurement on the financial markets: a meta-analysis approach. E-journal of Corporate Finance, 3 (11), 54-76

Vintilă, G., Păunescu, R. A., \& Gerghina S. C. (2015). Does corporate governance influences corporate financial performance? Empirical evidences for the companies listed on US markets. International Business Research, 8 (8), 27-44. http://dx.doi.org/10.5539/ibr.v8n8p27

Vo, D. H., \& Nguyen, T. M. (2014). The impact of corporate governance on firm performance: Empirical study in Vietnam International Journal of Economics and Finance, 6 (6), 1-12.

Wang, M. (2013). Value relevance on intellectual capital valuation methods: the role of corporate governance. Quality and Quantity, 47(2), 1213-1223. http://dx.doi.org/10.1007/s11135-012-9724-1

Weir, C. M., Laing, D., \& McKnight, P. J. (2002). Internal and external governance mechanisms: Their impact on the performance of large UK public companies. Journal of Business Finance and Accounting, 29, 579-611. http://dx.doi.org/10.1111/1468-5957.00444 
Woolridge, J. M. (2009), Introductory econometrics. A modern approach, fourth edition, South-Western, Canada.

Zeitun, R., \& Tian, G. (2007). Capital structure and corporate performance: evidence from Jordan. Australasian Accounting Business and Finance Journal, 1, 40-53.

Zhara, A. S. A., \& Pearce II, J. A. (1989), Boards of Directors and Corporate Financial Performance: A Review and Integrative Model. Journal of Management, 15(2), 291-334. http://dx.doi.org/10.1177/014920638901500208

\section{Notes}

Note 1. Family firms for their features are included within the high ownership concentrated firms (Baglioni and Colombo, 2013).

Note 2. Intellectual capital (IC) can be defined as the dynamic and firm-specific system of intangible resources and activities in gaining and sustaining firm competitive advantages (Reed et al., 2006; Martín-de-Castro et al., 2011). In the prevalent literature, IC is articulated into three abstract categories, which must interact to create company value: human capital, organizational (structural) capital and relational capital (Edvinsson and Malone, 1997; Meritum, 2002). Briefly, human capital (HC) is composed of tacit knowledge, capabilities, and competences possessed by the employees. Organizational capital (OC) is made up of structured knowledge in the form of patents, databases, procedures, etc., but it also comprises "softer" elements such as organizational and managerial processes, the organizational structure, the corporate culture, etc. Lastly, relational capital (RC) encompasses the relations which a company develops with its stakeholders, that is customers, suppliers, institutions, etc.

Note 3. The Italian National Stock Market Commission (Borsa Italiana) defines significant shareholdings as those exceeding 2 per cent of the capital.

Note 4. The question of which elements should be included in the VA figure has been the subject of controversies in the literature. In any event, the different figures of VA address different purposes (Haller, 1997; Morley, 1979). The choice to employ the net figure is justified by the consideration that, from a conceptual point of view, amortization and depreciation should be regarded as costs related structurally to the firm and then contributing to the creation of the VA, rather than to its distribution (Montrone, 2000).

Note 5. Values reported in the Beta column are the standardized versions of the regression coefficients, which are not dependent on the units of measurements of variables. As they are directly comparable, these values provide a better insight into the importance of a predictor in the model.

\section{Copyrights}

Copyright for this article is retained by the author(s), with first publication rights granted to the journal.

This is an open-access article distributed under the terms and conditions of the Creative Commons Attribution license (http://creativecommons.org/licenses/by/4.0/). 